\title{
Special Issue "Urban and Buildings Regeneration Strategy to Climatic Change Mitigation, Energy, and Social Poverty after a World Health and Economic Global Crisis"
}

\author{
Pilar Mercader-Moyano *(D) and Antonio Serrano-Jiménez (D) \\ Departamento de Construcciones Arquitectónicas I, University of Seville, 41012 Seville, Spain; aserrano5@us.es \\ * Correspondence: pmm@us.es; Tel.: +34-618-305-559 (P.M.-M.); +34-646-580-435 (A.S.-J.)
}

Citation: Mercader-Moyano, P.;

Serrano-Jiménez, A. Special Issue

"Urban and Buildings Regeneration Strategy to Climatic Change

Mitigation, Energy, and Social

Poverty after a World Health and

Economic Global Crisis".

Sustainability 2021, 13, 11850.

https://doi.org/10.3390/su132111850

Received: 22 October 2021

Accepted: 25 October 2021

Published: 27 October 2021

Publisher's Note: MDPI stays neutral with regard to jurisdictional claims in published maps and institutional affiliations.

Copyright: (c) 2021 by the authors. Licensee MDPI, Basel, Switzerland. This article is an open access article distributed under the terms and conditions of the Creative Commons Attribution (CC BY) license (https:// creativecommons.org/licenses/by/ $4.0 /)$.

\section{Introduction}

Throughout the 21st century, urban reports demand solutions to the obsolescence and aging process suffered by the existing buildings, due to the growth and expansion of cities that took place in the second half of the 20th century [1]. This context has meant that today, more than $40 \%$ of the European building stock is over 50 years old [2]. This factor together with continued global warming has led to world strategies on the adaptation and renovation of the built environment, that allow one to comply with current comfort, energy, and climatic requirements, and to achieve a sustainable urban transition by opting for bioclimatic conditioning techniques in different regions [3]. Additionally, the global crisis due to COVID-19 has supposed an adverse impact on urban regeneration of the built environment, with a recent world GDP drop of around 4.9\%, and an estimated $20-30 \%$ decrease in economic funds intended for building renovation, with new decision support systems required, in order to carry out feasible and appropriate action strategies [4].

In this context, global guidelines on urban renovation aim to support low-carbon energy transition through sustainable and viable renovation strategies [5]. The European Energy Performance of Buildings Directive [6] underlines the need to implement new procedures for retrofitting the building stock, ensuring viable and efficient operations to achieve energy targets, as well as to improve the comfort conditions of users, also in families with low income levels that represent an important barrier for carrying out the building renovation or in other vulnerable social groups in which the ageing population predominates and specific accessibility conditions are required for the adaptation of buildings [7].

Thus, the topic of this Special Issue is focused on "Urban and Buildings Regeneration Strategy to Climatic Change Mitigation, Energy, and Social Poverty after a World Health and Economic Global Crisis", in response to the main urban challenges of this 21st century, and taking into account the new socioeconomic scenario that emerged after the global health crisis. This Special Issue of Sustainability mainly focuses on:

Thus, it is important to identify and discuss architectural, environmental, and economic problems in the activity of the construction sector, putting special emphasis on alternatives that provide solutions to the main works of building rehabilitation, with special attention to the residential sector, as well as guaranteeing technical, social and economic in feasibility in the action proposals.

- Providing new tools and methods to support the diagnosis and an adequate decisionmaking in building renovation, also considering different scenarios of vulnerability in the architectural, social, and economic fields.

- Introducing sustainable design patterns in urban planning, along with establishing users' awareness guidelines to guarantee a sustainable urban transition under this new socioeconomic context in emerging countries.

- Optimising the use of resources, energy consumption, materials, and providing an adequate indoor and outdoor environmental quality in the building sector, ensuring 
an efficient management of all the construction phases, from the early design and decision-making, to guaranteeing a feasible building maintenance.

- Reactivating the construction sector, in the context of this world economic crisis, through solutions that strengthen the circular economy in eco-efficient building renovation and urban regeneration.

- Establishing an action proposal already carried out that serve as a reference for future actions, as an example of a sustainable, efficient pattern and towards an eco-efficient urban transition.

\section{Background and Contents}

Global targets on urban and social policies have recently established the urgency of adjusting technical and holistic decision support systems to effectively adapt and renovate the built environment, in their most vulnerable areas, in order to comply with current regulatory requirements and follow the main aims of the Sustainable Development Agenda for Sustainable Buildings [8].

Nowadays, a priority issue to deal with is the increase in obsolescence and deterioration in existing neighbourhoods, due to the expansion of cities carried out in the second half of the 20th century, which increasingly affects the guarantee of well-being and quality of life in society. European reports state that more than $40 \%$ of existing buildings were built over 50 years ago, and around $85 \%$ of residential environments are over 25 years old, demonstrating the need to design appropriate assessment and valuation models that incorporate technical, social and economic disciplines to decide the most appropriate actions to promote towards an effective and sustainable integrated urban regeneration in the coming years.

The global health crisis due to COVID-19 will have an impact on economic, social, and urban policies in the near future, with a world GDP drop of around $4.9 \%$ in 2020, and an expected decrease in the distribution of economic funds and priorities towards the urban regeneration of cities, which will make a higher challenge to adjust actions and optimise public resources in the urban, social, and housing fields [9]. This situation highlights the need to help governments with indicators that allow one to objectively detect certain parameters and urgencies that must be addressed with public investments, considering the real needs of users and meeting sustainable development goals [10], as an economic promotion for recovering the declining GDP in the post-COVID-19 crisis from the sector of construction, with this impact being more pronounced in vulnerable countries where extreme poverty is estimated to return to percentages of 20 years ago [11]. These alarming data raise the creation of new mechanisms that evaluate the vulnerability of urban spaces and buildings, involving important regulatory non-compliances and daily inconveniences for users, that must be quantified from multiple approaches to identify action priorities in the built environment [6].

Faced with this technical, social, and economic scenario, the circular economy is presented as an effective and sustainable solution for an integrated urban regeneration, at the same time that it can stimulate the vulnerability of emerging countries with effective action strategies. The incorporation of circular economy patterns allows generating more jobs, more industries, and the design of tools can guarantee economic viability with an optimization of resources. Thus, the current inefficiency of the building stock, together with the social precariousness, must be faced by an effective stimulus through research and the dissemination of good practices in the area of urban regeneration, ensuring, at the same time, the basic conditions of comfort, habitability, and safety.

\section{Publications and Insights of the Special Issue}

Starting with the introduction of sustainable criteria, circular economy and ecoefficient patterns in the urban regeneration process of the built environment under the current socioeconomic context, the research developed by Soto et al. [12] incorporates a detailed review and assessment of multiple environmental parameters and criteria required 
in different guides and regulations of the Spanish public administration, also compared with other international guidelines, carrying out a discussion of their usefulness and replicability as well as concluding with different specifications required to be developed and incorporate into new future environmental policies and strategies in the construction sector, especially in those promoted by the public administration.

Following this scope of application, the paper presented by Herrera-Limones et al. [13] is already making progress on this issue, and incorporates a new methodological proposal to satisfy the Sustainable Development Goals (SDGs) in the design of healthy and sustainable actions in the urban environment; for this, it contributes two new tools: the aura method and the aura matrix, both of them having been applied, tested, and compared in two architectural proposals presented to the Solar Decathlon Latin America of the Aura Team of the University of Seville, as a two-way learning between teachers and students. The results of the application allow one to demonstrate that both tools provide two useful concepts to incorporate multidisciplinary approaches to health, economic viability, or well-being requirements in the action proposals of the urban design of our cities, with the ultimate aim of improving the quality of life of citizens, from a transversal and sustainable perspective, fulfilling the established 2030 Agenda.

With a particular focus on the socioeconomic instability generated by the COVID-19 health crisis, the research developed by Mercader-Moyano et al. [14] has contributed in this issue with a novel assessment methodology for existing housing environments occupied by population groups that are in a situation of social vulnerability. This model has introduced the design of 51 different indicators of satisfaction, related to terms of habitability, grouped into different technical and social disciplines. The novelty of this study is that a tool is generated that combines social questionnaires with technical inspections to identify the main deficiencies and precarious conditions of housing environments, being this assessment methodology applied and corroborated in a representative neighbourhood of Mexico, which has allowed us to demonstrate the usefulness of these methodological mechanisms to prioritise highly effective actions in a context of different emergency scenarios.

In line with this previous study, on the situation of economic vulnerability generated by the pandemic, the study carried out by Alba-Rodríguez et al. [15] incorporates a deep reflection on the problem of energy poverty and its increase due to global warming, presenting an assessment model for evaluating retrofitting projects that considers real energy consumption, comfort demands, tenant's health, and the economic situation of users, therefore taking into account the occupant behaviour due to the limitation of their economic resources. This model incorporates, as a novelty, an Index of Vulnerable Homes to quantify the suitability of the actions and the adaptability to climate change of certain proposals, generating a new approach to energy poverty and providing more complete information for the adaptation capacity of the owners according to the climate variability and the different economic scenarios of intervention costs and energy costs that they can afford.

Another key aspect to address in the social vulnerability that exists in the built environment is the aging of the population, since there are increasingly elderly people living in obsolete and inadequate housing. This issue is addressed in the Special Issue in the research published by Agost-Felip et al. [16], which presents a study that brings together the specific needs of the elderly in the public open space, and designs a model to assess the vulnerability of public space through indicators from this particular approach. As a main contribution, this model and this approach implies recognizing the importance of the elderly in making decisions about the design of urban planning actions, in order to create age-friendly environments and even cities. Additionally, Gómez-Jiménez et al. [17] identify key aspects to take into account to satisfy the needs of the elderly in social housing or in specific social services, in order to be introduced in upcoming public policies. In order to have obtained important insights, the procedure carried out is to establish the main characteristics for an "ideal" adequate housing environment for elderly users, taking into account the existing characteristics and the regulations in force in Spain, launching 
new opportunities to propose a new Spanish regulation on elderly needs in the built environment.

Carrying out a special focus on ideas and new contributions regarding action proposals in housing renovation, different publications have incorporated new findings and important insights. The study published by Pitarch et al. [18] analyses the important impact of rehabilitating the roofs towards a sustainable regeneration of the existing building. The study introduces theoretical benefits and highlights the potential of gratings with regard to energy saving, the opportunity to incorporate green areas and other social uses. The different rehabilitation solutions were proposed and applied in a case study in Castellón, and their usefulness was discussed from different sustainable, economic, social and architectural criteria.

Following this line of research, the paper published by Domínguez-Torres et al. [19] introduces a new optimized and innovative construction system applicable to roofs that combines thermal insulation techniques with different thicknesses and solar reflective coatings, carrying out a dynamic analysis that quantifies savings and performance throughout the life cycle. The results show that the ideal balance between combining cool roof emissivity and insulation layer thickness produces an ideal solution for social housing renovation, with an average cost reduction of $63 \%$, as well as good performance in its life cycle analysis, from an energy and economic point of view.

This Special Issue also incorporates two published papers that include innovative experiences of real application in different buildings and architectural elements. This real application is a confirmation of good, sustainable, and efficient practices for transforming the built environment. First, the publication by Ramos-Carranza et al. [20] describes the research methodology carried out, based on scientific observation, for the design of a prefabricated construction solution for rehabilitation for the application in water mills, as a family of singular and representative buildings that today require specific solutions for their renovation. The paper confirms the usefulness of this research methodology, and the environmental and economic benefits of the intervention strategy designed, carried out in "El Rodezno" as a case study, promoting the acceptance of prefabrication and its advantages for a circular economy.

Finally, the study presented by Calvo-Serrano et al. [21] presents a practical experimental case that shows that it is possible to carry out an eco-sustainable rehabilitation in buildings of special protection using the church of "Santiago Apostol" in Montilla, in the province of Córdoba, which is included in the list of Assets of Cultural Interests from 2001. The study details the eco-efficient criteria taken into account to carry out a design and decision-making methodology that has made it possible to quantify some indicators in different intervention strategies, which has made it possible to select a feasible proposal that has guaranteed environmental, economic and social sustainability for the inhabitants of this municipality.

As a final reflection, the contributions made in the 10 papers that have been selected for publication in this Special Issue introduce important findings towards a sustainable, satisfactory and efficient urban regeneration in the face of a new socioeconomic scenario caused by the pandemic. The results, ideas, approaches, and conclusions are expected to be of great significance for different researchers of these lines of action, and to be a reference for future studies of great impact, allowing the generation of important synergies that lead to a reconversion of the built environment to the current needs of society.

Author Contributions: Conceptualization and methodology, P.M.-M. and A.S.-J.; investigation and writing-original draft preparation, A.S.-J.; writing—review and editing and supervision, P.M.-M. All authors have read and agreed to the published version of the manuscript. 
Funding: This special issue has been possible thanks to the funding received by the research funds of the University of Seville "Ayuda del VI Plan Propio de Investigación y Transferencia de la Universidad de Sevilla 2021, para Proyectos de Investigación Precompetitivos (IV.4)" through the research project "REGEBIM" (Gestión integral BIM de soluciones de rehabilitación de envolventes, con criterios de economía circular y sostenibilidad regenerativa, como impulso a la recuperación económica). This work was also developed thanks to the collaboration of the Andalusian Government (Junta de Andalucía-Consejería de Economía, Innovación y Ciencia) through a postdoctoral contract DOC-00950 granted to Antonio Serrano-Jiménez.

Acknowledgments: We would like to express our gratitude to all the authors and reviewers for their contributions and constructive support and comments. Honestly, they have provided important insights to increase the scientific quality of this Special Issue, on such an important approach for the built environment. We also thank the editorial assistance office of MDPI, which demonstrated interest and effort to support during the process of reviewing and publishing this volume.

Conflicts of Interest: The authors declare no conflict of interest.

\section{References}

1. Santangelo, A.; Tondelli, S. Occupant behaviour and building renovation of the social housing stock: Current and future challenge. Energy Build. 2017, 145, 276-283. [CrossRef]

2. Eurostats, Newsrealease-Euroindicators February 2019. Available online: https://ec.europa.eu/eurostat/documents/2995521/ 9967985/3-10072019-BP-EN.pdf/e152399b-cb9e-4a42-a155-c5de6dfe25d1 (accessed on 5 October 2021).

3. WHO. Supporting Older People during the COVID-19 Pandemic Is Everyone's Business. 2020. Available online: http:/ / www.euro.who.int/en/health-topics/health-emergencies/coronaviruscovid19/news/news/2020/4/supportingolderpeople-during-the-covid-19-pandemic-is-everyones-business. (accessed on 7 October 2021).

4. Mercader-Moyano, P.; Morat, O.; Serrano-Jiménez, A. Urban and social vulnerability assessment in the built environment: An interdisciplinary index-methodology towards feasible planning and policy-making under a crisis context. Sustain. Cities Soc. 2021, 73, 103082. [CrossRef]

5. European Commission. An EU Strategy on Heating and Cooling (COM(2016) 51 Final); Brussels, Belgium, 16 February 2016. Available online: https: / / ec.europa.eu/transparency / documents-register/detail?ref=COM(2016)51\&lang=en (accessed on 24 October 2021).

6. European Commission. Directive (EU) 2018/844 of the European Parliament on the energy performance of buildings and energy efficiency. Off. J. Eur. Union 2018, 156, 75-91.

7. Serrano-Jiménez, A.; Femenías, P.; Thuvander, L.; Barrios-Padura, Á. A multi-criteria decision support method towards selecting feasible and sustainable housing renovation strategies. J. Clean. Prod. 2020, 278, 123588. [CrossRef]

8. GBCe, European Agenda for Sustainable Buildings. 2020. Available online: https://gbce.es/documentos/Agenda-de-la-UEpara-la-edificacion-sostenible.pdf. (accessed on 20 July 2021).

9. OECD, GDP. 2021. Available online: https://data.oecd.org/gdp/gross-domestic-product-gdp.htm. (accessed on 18 August 2021).

10. ONU. Transforming Our World: The 2030 Agenda for Sustainable Development; United Nations: New York, NY, USA, 2015.

11. The World Bank. Supporting Countries in Unprecedented Times. World Bank Annu. Rep. 2020, 1-106. Available online: https:/ / www.worldbank.org/en/about/annual-report/world-bank-group-downloads. (accessed on 18 March 2021).

12. Soto, T.; Escrig, T.; Serrano-Lanzarote, B.; Matarredona, N. An Approach to Environmental Criteria in Public Procurement for the Renovation of Buildings in Spain. Sustainability 2020, 12, 7590. [CrossRef]

13. Herrera-Limones, R.; LopezDeAsiain, M.; Borrallo-Jiménez, M.; García, M.T. Tools for the Implementation of the Sustainable Development Goals in the Design of an Urban Environmental and Healthy Proposal. A Case Study. Sustainability 2021, $13,6431$. [CrossRef]

14. Mercader-Moyano, P.; Morat-Pérez, O.; Muñoz-González, C. Housing Evaluation Methodology in a Situation of Social Poverty to Guarantee Sustainable Cities: The Satisfaction Dimension for the Case of Mexico. Sustainability 2021, 13, 11199. [CrossRef]

15. Alba-Rodríguez, M.; Rubio-Bellido, C.; Tristancho-Carvajal, M.; Castaño-Rosa, R.; Marrero, M. Present and Future Energy Poverty, a Holistic Approach: A Case Study in Seville, Spain. Sustainability 2021, 13, 7866. [CrossRef]

16. Agost-Felip, R.; Ruá, M.; Kouidmi, F. An Inclusive Model for Assessing Age-Friendly Urban Environments in Vulnerable Areas. Sustainability 2021, 13, 8352. [CrossRef]

17. Gómez-Jiménez, M.; Antonio, V.-Y. Key Elements for a New Spanish Legal and Architectural Design of Adequate Housing for Seniors in a Pandemic Time. Sustainability 2021, 13, 7838. [CrossRef] 
18. Pitarch, Á.; Ruá, M.; Reig, L.; Arín, I. Contribution of Roof Refurbishment to Urban Sustainability. Sustainability $2020,12,8111$. [CrossRef]

19. Domínguez-Torres, C.-A.; Domínguez-Torres, H.; Domínguez-Delgado, A. Optimization of a Combination of Thermal Insulation and Cool Roof for the Refurbishment of Social Housing in Southern Spain. Sustainability 2021, 13, 10738. [CrossRef]

20. Ramos-Carranza, A.; Añón-Abajas, R.; Rivero-Lamela, G. A Research Methodology for Mitigating Climate Change in the Restoration of Buildings: Rehabilitation Strategies and Low-Impact Prefabrication in the "El Rodezno" Water Mill. Sustainability 2021, 13, 8869. [CrossRef]

21. Calvo-Serrano, M.; Castillejo-González, I.; Montes-Tubío, F.; Mercader-Moyano, P. The Church Tower of Santiago Apóstol in Montilla: An Eco-Sustainable Rehabilitation Proposal. Sustainability 2020, 12, 7104. [CrossRef] 